\title{
Analisis Sistem Persediaan Pada PT. Mega Prabu Mandiri Cabang Lubuklinggau
}

\author{
Yayuk Marliza', Kusnadi Yudha Wiguna ${ }^{2}$, Izmi hilmika ${ }^{3}$ \\ ${ }^{1}$ Fakultas Ekonomi Universitas Musi Rawas, Marlizayayuk77@gmail.com \\ ${ }^{2}$ Fakultas Ekonomi Universitas Musi Rawas \\ ${ }^{3}$ Fakultas Ekonomi Universitas Musi Rawas
}

\begin{abstract}
The aim of this study to analyze tht inventory system at PT. Mega Prabu Mandiri Lubukliggau. This is qualitative study through primary and secondary data. The inventory system of this study is consisted of goods purchasement, goods sale, financial report, accounting records, inventory transaction prochedure and application control. At the stage of analysis, all data are analyzed descriptively. The results showed that PT. Mega Prabu Mandiri Lubukliggau branch in purching and selling medical equipment supplies, the reports generated (inventory status report, inventory types reports, reorder reports and inventory physical count reports), accounting records used and application control to the inventory system are not in accordance with theory existing inventory system. All records have been computerized and the results of the reports are based on the application used by PT. Mega Prabu Mandiri Lubukliggau branch
\end{abstract}

Keywords: Inventory System.

\begin{abstract}
ABSTRAK
Rumusan masalah dalam penelitian ini adalah bagaimana sistem persediaan pada PT. Mega Prabu Mandiri Cabang Lubuklinggau. Tujuannya untuk mengetahui sistem persediaan pada PT. Mega Prabu Mandiri Cabang Lubuklinggau. Penelitian ini termasuk penelitian kualitatif. operasional variabel penelitian ini adalah sistem persediaan dengan indikator Pembelian Barang, Penjualan Barang, Laporan yang Dihasilkan, Catatan Akuntansi, Prosedur Pemrosesan Transaksi Persediaan, Pengendalian Aplikasi. Data yang digunakan adalah primer dan sekunder. Teknik analisa data yang digunakan adalah analisa diskriptif. Hasil penelitian menunjukkan PT. Mega Prabu Mandiri Cabang Lubuklinggau dalam melakukan pembelian dan penjualan persediaan alat kesehatan, Laporan yang dihasilkan (laporan status persediaan, laporan perjenis persediaan, laporan pemesanan kembali, dan laporan hasil perhitungan fisik persediaan), catatan akuntansi yang digunakan, dan pengendalian Aplikasi terhadap sistem persediaan sudah sesuai dengan teori sistem persediaan yang ada. Prosedur pemrosesan transaksi persediaan sudah sesuai dengan teori sistem persediaan karena ada file ringkasan buku besar dan laporan kontrol. Semua pencatatan sudah dilakukan secara komputerisasi dan hasil laporan sudah berdasarkan aplikasi yang digunakan oleh PT. Mega Prabu Mandiri Cabang Lubuklinggau.
\end{abstract}

Kata Kunci : Sistem Persediaan

\section{A. PENDAHULUAN}

Persediaan barang dagang merupakan aset yang sangat penting terutama bagi perusahaan dagang yang melakukan aktivitas penjualan. Persediaan perusahaan dagang dicatat sebagai persediaan barang dagangan (merchandise inventory) yaitu berupa barang yang dibeli untuk dijual dalam usaha normalnya. Persediaan juga merupakan harta kekayaan perusahaan yang memiliki peranan penting dalam operasi bisnis dalam perusahaan. Persediaan merupakan salah satu elemen terpenting dalam neraca, oleh karena itu dibutuhkan ketelitian yang ekstra dari segi pencatatan, penghitungan persediaan, penyimpanan persediaan serta berbagai perlakuan untuk mengelola persediaan yang ada agar terhindar dari 
kerugian yang disebabkan oleh kelalaian bahkan kecurangan. Menyadari hal tersebut, sebuah sistem akuntansi persediaan yang dirancang haruslah efektif dan efisien serta diharapkan dapat berjalan sesuai dengan tujuan perusahaan.

Sistem persediaan merupakan mutasi persediaan dari gudang yang akan dikeluarkan karena adanya transaksi penjualan barang dagang. Sistem akuntansi memberikan informasi untuk digunakan oleh manajer dalam menjalankan operasi perusahaan. Sistem akuntansi juga memberikan informasi untuk pihak-pihak lain yang berkepentingan dalam menilai kinerja dan kondisi ekonomi perusahaan. Berkembangnya kebutuhan informasi telah mendorong perkembangan akuntansi sebagai suatu sistem informasi, perubahan ini berkaitan erat dengan penerapan teknologi pengolahan data yang lebih efisien dan dapat mengolah informasi yang lebih banyak. Sistem akuntansi menjadi sangat penting dalam suatu organisasi, suatu sistem yang kurang dalam memperoleh informasi akan mengakibatkan sistem menjadi luruh, mengecil dan akhirnya berhenti. Oleh karena itu agar sistem terus berjalan maka sistem tersebut harus tetap memperoleh informasi yang cukup dan berguna.

PT. Mega Prabu Mandiri adalah perusahaan yang melakukan kegiatan penjualan barang berupa alat-alat kesehatan. Barang yang dijual oleh perusahaan ini cukup banyak, tetapi tidak semua item barang dagang tersebut tersedia di perusahaan. Barang dagang yang tersedia di PT. Mega Prabu Mandiri Cabang Lubuklinggau diantaranya adalah Mess Braun, Mess No, Film Di-HL, IV Catether No.24, Terumo, Transfusiset, Terumo, Infuset Makro dan Mikro Terumo, Stomach Tube, Fedding No.5, Spuit, Strip Urine, Spinocan, Treeway, Clhoretyl, Lomatuel, Oxygen, Bloodbag, Nausafe, Gel Maske,r Alkohol, Aproon, Aseptan, Balon Tensi ,Colos,Tomibag,Control hema ,kapsul kosong, Deck Glask, Tabung Edta, Foley Catether, Feeding Tube. HIV SD, Kapas, Kertas ECG, Kassa, Pensil, Couter, Pot Plastik, Suction, Catether, Selang,dan lain-lain. Perusahaan ini melayani penjualan alat-alat kesehatan untuk beberapa konsumen yang ada diseputar Lubuklinggau, Musi Rawas dan Musi Rawas Utara.

Berdasarkan hasil pengamatan,belum belum tergambar informasi yang jelas dalam melakukan pengelolaan persediaan, perusahaan sering terlambat mengirimkan barang pesanan pelanggan, semua kegiatan dilakukan oleh karyawan, belum ada evaluasi dan pengendalian dari pimpinan. Jika kondisi memungkinkan pimpinan langsung ikut serta dalam perhitungan persediaan barang yang ada digudang akan tetapi kalau tidak bisa pimpinan perusahaan hanya cukup mengetahui bahwa rekapitulasi persediaan telah selesai dibuat dan tanpa melakukan pengecekan lebih lanjut. Perusahaan masih mengabaikan fungsi masing-masing bagian sehingga sistem akuntansi dinilai masih lemah.

\section{B. KAJIAN TEORI}

Persediaan adalah meliputi semua barang yang dimiliki dengan tujuan untuk dijual kembali dan/atau dikonsumsi dalam operasi normal perusahaan. Persediaan adalah salah satu aktiva terpenting pada perusahaan dagang dan manufaktur, karena hampir seluruh pendapatannya diperoleh dari penjualan barang sebagai persediaan (Harnanto,2012:222). Pengertian ini sejalan dengan pendapat dari Imam Santoso (2010:239), bahwa persediaan adalah aktiva yang ditujukan untuk dijual atau diproses lebih lanjut untuk menjadi barang jadi dan kemudian dujual sebagai kegiatan utama perusahaan. Dalam pengertian ini aktiva yang dimiliki perusahaan bukan untuk dijual tidak akan diperlakukan sebagai persediaan. 
Penggolongan persediaan sangat dipengaruhi oleh sifat dan jenis usaha perusahaan yang bersangkutan. Bagi perusahaan dagang yang didalam usahanya adalah membeli dan menjual kembali barang dagangannya, pada umumnya persediaan yang dimiliki diklasifikasikan sebagai berikut:

1. Persediaan barang dagangan, untuk menyatakan barang-barang yang dimiliki dengan tujuan akan dijual kembali dimasa yang akan datang. Barang-barang ini secara phisik tidak akan berubah sampai dengan barang tersebut dijual kembali.

2. Lain-lain persediaan, seperti umpamanya supplies kantor (toko), dan alat-alat pembungkus dan lain sebagainya. Barang-barang ini biasanya akan dipakai (dikonsumsikan) dalam jangka waktu relatif pendek dan akan dibebankan sebagai beban administrasi dan umum atau beban pemasaran. Oleh karena itu, biasanya terhadap jenis persediaan ini diperlakukan sebagai biaya (yang dibayar dimuka) atau persediaan supplies.

Menurut Krismiaji (2010:399-402), sistem persediaan merupakan sebuah sistem yang memelihara catatan persediaan dan memberitahu manajer apabila jenis barang tertentu memerlukan penambahan. Perusahaan dagang menggunakan sistem persediaan untuk menjaminbahwa barang tersedia untuk dijual kembali. Sebuah sistem persediaan memproses dua jenis transaksi yaitu transaksi pembelian barang dan transaksi penjualan barang. Jadi sistem persediaan meliputi kegiatan sebagai berikut:

a. Pembelian Barang

Jurnal untuk mencatat transaksi ini tergantung pada metode yang digunakan untuk akuntansi persediaan, yaitu metode periodic dan metode perpetual. Dengan metode periodik, perusahaan tidak menyelenggarakan catatan yang menggambarkan perubahan persediaan dari waktu ke waktu. Catatan yang diselenggarakan adalah catatan untuk menampung transaksi pembelian barang dagangan. Catatan ini diberi nama rekening Pembelian. Dalam hal ini, perusahaan menentukan persediaan awal dan persediaan akhir dengan melakukan perhitungan fisik persediaan. Secara periodik perusahaan juga menghitung harga pokok penjualan dari saldo awal dan saldo akhir periode dan saldo rekening pembelian. Jurnal untuk mencatat transaksi pembelian adalah:

(Debit) Pembelian ................................... $x x x x$

(Kredit) Utang Dagang ...XXXX

Dengan metode perpetual, perusahaan menyelenggarakan catatan yang menampung transaksi mutasi persediaan. Dengan catatan ini, maka posisi persediaan dapat diketahui setiap saat, karena dengan digunakan komputer untuk mengolah data akuntansi, kendala yang dihadapi pada masa lalu dapat dieliminasi, sehingga aktivitas pencatatan dapat dilakukan dengan cepat dan akurat, serta menghasilkan berbagai informasi yang penting untuk pengendalian perusahaan. Jika perusahaan membeli barang, maka pembelian ini akan dicatat dalam rekening persediaan barang, sehingga otomatis menambah kuantitas dan menambah biaya. Pencatatan dalam jurnal dilakukan sebagai berikut:

(Debit) Persediaan Barang Dagangan $x X X X X$

(Kredit) Utang Dagang $x x x x$

Jika perusahaan menjual barang, maka perusahaan akan mengurangi kuantitas dan biaya/kos langsung pada rekening persediaan. Dengan cara ini maka 
perusahaan akan selalu mengetahui berapa jumlah persediaan yang ada digudang, sehingga dapat memutuskan kapan persediaan barang perlu ditambah. dengan demikian perusahaan akan terhindar dari resiko kehabisan barang.

b. Penjualan Barang

perusahaan mencatat harga pokok barang yang terjual dalam sebuah rekening buku besar yang berjudul Harga Pokok Penjualan. Bagaimana perusahaan menentukan nilai harga pokok ini sangat tergantung pada metode persediaan yang digunakan. Jika perusahaan menggunakan metode periodik, maka perusahaan tidak perlu membuat jurnal ketika terjadi transaksi penjualan. Dengan demikian, harga pokok penjualan dihitung dengan menambahkan nilai pembelian ke harga pokok persediaan awal. Hasil penjumlahan ini disebut harga pokok barang yang tersedia untuk dijual. Angka ini selanjutnya akan dikurangi dengan harga pokok persediaan akhir untuk memperoleh angka final yang disebut harga pokok penjualan. Jika perusahaan menggunakan metode perpectual, perusahaan akan mendebit rekening Harga Pokok Penjualan dan mengkredit rekening Persediaan pada saat terjadinya transaksi penjualan. Pada akhir periode, saldo akhir pada rekening harga pokok penjualan merupakan harga pokok barang yang dijual selama satu periode akuntansi.

c. Laporan yang dihasilkan

Sistem persediaan juga menghasilkan berbagai macam laporan. Laporan yang dihasilkan mencakup laporan status persediaan, laporan per jenis persediaan, laporan pemesanan kembali, dan laporan hasil perhitungan fisik persediaan.

d. Catatan Akuntansi

perusahaan yang menggunakan metode perpetual membutuhkan sebuah rekening pembantu persediaan untuk mencatat perubahan yang terjadi pada setiap jenis barang. Rekening pembantu ini sering disebut dengan kartu persediaan. Dalam kartu tersebut selain dicatat bertambah dan berkurangnya nilai persediaan per jenis barang, juga dicatat bertambah dan berkurangnya kuantitas persediaan, dan saldo yang baru. Dalam sistem berbasis computer, apabila perusahaan masih menggunakan pendekatan file, maka tata cara pencatatan sama dengan sistem manual. Catatan akuntansi yang diselenggarakan terdiri atas file induk (master file) dan file transaksi (transaction file)

e. Prosedur Pemrosesan Transaksi Persediaan

Apabila sistem persediaan diselenggarakan secara manual, maka sistem ini sudah menjadi satu (tergabung) dalam siklus pendapatan dan siklus pengeluaran. Jika sistem persediaan diselenggarakan dengan menggunakan komputer.

f. Pengendalian Aplikasi

pengendalian aplikasi untuk sistem persediaan dibagi menjadi pengendalian input, pengendalian proses, dan pengendalian output.

\section{METODE PENELITIAN}

Variabel dalam penelitian Sistem Persediaan, yaitu sebuah sistem yang memelihara catatan persediaan dan memberitahu manajer apabila jenis barang tertentu memerlukan penambahan. Perusahaan dagang menggunakan sistem persediaan untuk menjamin bahwa barang tersedia untuk dijual kembali. Indikator 
yang digunakan adalah Pembelian Barang, Penjualan Barang, Laporan yang Dihasilkan, Catatan Akuntansi, Prosedur Pemrosesan Transaksi Persediaan, Pengendalian Aplikasi.

Penelitian ini menggunakan data kualitatif. Jenis dan sumber data penelitian menggunakan data internal dari PT. Mega Prabu Mandiri Cabang Lubuklinggau. Data yang digunakan dalam penelitian ini adalah data sekunder dan data primer. data primer diperoleh dari hasil pertanyaan-pertanyan pada saat wawancara dengan pihak yang terkait dengan penelitian ini, data sekunder berasal dari objek penelitian yaitu data persediaan tahun 2020.

Teknik analisis data yang digunakan dalam penelitian ini adalah teknik analisis data deskriptif yaitu menganalisis data dengan mendeskripsikan atau mengambarkan data-data yang sudah dikumpulkan yang berkenaan dengan sistem informasi akuntansi persediaan pada PT. Mega Prabu Mandiri Cabang Lubuklinggau. Analisis data dilakukan dengan mendiskripsikan pengertian Sistem persediaan serta indikatornya, mendeskripsikan pengertian persediaan serta mengumpulkan data tentang persediaan, dan menentukan apakah sistem persediaan pada PT. Mega Prabu Mandiri Cabang Lubuklinggau sudah berjalan optimal atau belum dan sesuai dengan standar sistem akuntansi persediaan.

\section{HASIL DAN PEMBAHASAN}

\section{Pembelian Barang (Alat Kesehatan)}

Pembelian barang (alat-alat kesehatan) pada PT. Mega Prabu Mandiri Cabang Lubuklinggau selalu dicatat dalam formulir pembelian yang fungsinya untuk mencatat pembelian per item setiap tanggal atau sesuai periode sehingga mudah dipahami. PT. Mega Prabu Mandiri Cabang Lubuklinggau dalam melakukan pembelian persediaan alat kesehatan didasarkan tingkat kebutuhan pada saat sekarang yang disebabkan adanya permintaan barang dari konsumen maupun pembeli umum. Pembelian dilakukan berdasarkan rekap barang yang tidak ada digudang dan persediaan yang masih sedikit atau tersedia digudang.Untuk penerimaan barang yang dibeli maka bagian gudang atau karyawan harus melakukan pengecekan langsung terhadap barang yang datang. Pembelian pada PT. Mega Prabu Mandiri Cabang Lubuklinggau dilakukan dengan dua cara, pertama pembelian secara langsung dimana pembelian barang-barang bahan habis pakai ( BHP) dan barangnya sudah tersedia di gudang. Kedua pembelian dengan menggunakan PO (Purchase Order) dimana pembelian ini dilakukan karena barang yang dipesan merupakan barang-barang yang berukuran besar.

Barang yang pembeliaannya lewat PO biasanya menunggu selama kurang lebih satu minggu. Apabila barang datang dari distributor yang harus dilakukan oleh karyawan bagian gudang adalah barang harus di cek terlebih dahulu (quantity) apakah jumlahnya sudah sesuai dengan pesanan, keadaan barang (fisik) apakah masih bagus atau ada yang cacat, karyawan melakukan pencatatan No. Lot / badtch dan Expire Date barang, memasukkan ke kartu stok (persediaan) barang, melakukan kros cek faktur distributor dan barang yang datang sesuai atau tidak dengan PO, karyawan harus rutin mengecek barang digudang sesuai atau tidak antara kartu stok (persediaan), computer, dan fisik,rutin di cek stok barang yang hampir habis untuk segera dipesan, rutin Isi table suhu dan temperature gudang, kebersihan di gudang dan kantor di perhatikan, dan Penyusunan barang di kelompokkan sesuai nama barang, jarak antar barang min. 5 cm.Rekap pembelian barang dagang 
menggambarkan tanggal entri transkasi, nama distributor, nomor faktur, tanggal faktur, tanggal jatuh tempo, nama barang, kuantitas, kemasana PT. Mega Prabu Mandiri Cabang Lubuklinggau sudah ada fungsi pembelian dan sudah melakukan pencatatan pembelian.

\section{Penjualan}

Penjualan barang (alat-alat kesehatan) fungsinya untuk melihat penjualan barang ke konsumen per tanggal atau sesuai periode yang di cari. PT. Mega Prabu Mandiri Cabang Lubuklinggau dalam melakukan penjualan sudah melakukan pencatatan ke dalam komputerisasi. Penjualan alat kesehatan biasanya sudah berdasarkan pemesanan dari pelanggan akan tetapi ada juga dari konsumen mandiri. Rekap penjualan alat kesehatan PT. Mega Prabu Mandiri Cabang Lubuklinggau menjelaskan nomor faktur penjualan, tanggal penjualan alat kesehatan, tanggal jatuh tempo pembayaran, nama konsumen yang sudah menjadi pelanggan PT. Mega Prabu Mandiri Cabang Lubuklinggau dan nama konsumen mandiri dan total penjualan atas peralatan kesehatan yang dijual. Total penjualan pada bulan Februari 2021 sebanyak 57 transaksi dengan total penjualan sebesar Rp 131.633.382,00 penjualan ini kepada Klinik Utama Mata Sriwijaya, RSUD Rupit, RS AR Bunda Lubuklinggau, Klinik Dwisari, Klinik Citra Adinda, Apotik IKO Farma, dan pembelian umum.

Penjualan peralatan kesehatan pada PT. Mega Prabu Mandiri Cabang Lubuklinggau ada yang secara tunai dan ada penjualan yang pembayarannya jatuh tempo. Penjualan tunai dilakukan pada konsumen mandiri dan penjualan yang berdasarkan jatuh tempo untuk konsumen tetap perusahaan diantaranya Rumah Sakit AR Bunda Lubuklinggau, Rumah Sakit Umum Daerah Rupit, dan masih banyak lagi.Untuk menjaga kerjasama yang baik dengan konsumen atau pelanggan tetap dan pembeli umum maka perusahaan harus selalu menjaga kepercayaan yang sudah terjalin selama ini dan jangan sampai ada keterlambatan dalam pengiriman barang yang dibeli dan kualitas harus selalu diperhatikan. PT. Mega Prabu Mandiri Cabang Lubuklinggau sudah ada fungsi penjualan dan sudah melakukan pencatatan penjualan persediaan.

\section{Laporan yang dihasilkan}

Laporan yang dihasilkan PT. Mega Prabu Mandiri Cabang Lubuklinggau berkaitan dengan persediaan mencakup laporan status persediaan, laporan per jenis persediaan, laporan pemesanan kembali, dan laporan hasil perhitungan fisik persediaan. uraian rinci untuk setiap jenis laporan dapat dilihat pada diskripsi berikut ini:

a. Laporan Status Persediaan (Inventory Status Report)

Laporan status persediaan pada PT. Mega Prabu Mandiri Cabang Kota Lubuklinggau biasanya berisi daftar seluruh jenis persediaan, kuantitas, kemasan dan stok (persediaan) di gudang. Laporan ini memberikan penjelasan tentang persediaan yang yang ada digudang. Sistem computer mencetak laporan ini setiap sebulan sekali tetapi apabila diperlukan sewaktu-waktu laporan juga bisa dicetak akan tetapi laporan dibuat sebulan sekali. Karyawan menggunakan laporan ini untuk mengetahui kuantitas yang tersedia dan sekaligus sebagai alat kontrol persediaan yang ada digudang.Jika melihat persediaan barang digudang berdasarkan daftar alat-alat kesehatan keseluruhan jenis persediaan ada 480 item yang dijual oleh PT. Mega Prabu Mandiri Cabang Lubuklinggau. Setelah dilakukan pemeriksaan atau stock 
opname pada bulan Januari 2021 menunjukkan laporan hasil pemeriksaan barang yang tersedia digudang tidak sebanyak 480 item lagi karena banyak barang yang sudah terjual, sehingga laporan status persediaan berdasarkan stok yang tersedia dan yang ada digudang pada PT. Mega Prabu Mandiri Cabang Lubuklinggau.

b. Laporan per jenis Persediaan (Query Inventory Item)

Pada PT. Mega Prabu Mandiri Cabang Lubuklinggau sudah membuat laporan per jenis persediaan karena untuk melihat perediaan tinggal melihat kartu stok (persediaan) yang ada digudang dan bisa melihat ke komputer. Jadi karyawan perusahaan jika ingin mengetahui kuantitas per jenis persediaan yang tersedia dengan melihat laporan stok (persediaan) digudang. Yang ditampilkan pada kartu stock (persediaan) yaitu nomor, tanggal, keterangan, jenis SA (saldo awal), BK (barang keluar), BM (barang masuk), BMG (barang masuk gudang), RBK (retur barang keluar), SO (stock opname), KSO (koreksi stock opname), kode barang, nama barang, masuk, keluar saldo. Selain itu untuk mengetahui informasi tersebut, bisa langsung mencetak ke kertas atau melihat di layar monitor mengenai data stok (persediaan) barang yang ada digudang.

Laporan per jenis persediaan untuk memudahkan dalam penelusuran barang atau stok (persediaan) barang yag ada digudang dan memudahkan bagian pembelian juga dalam melakukan rekap barang yang akan dipesan. Kartu stok menggambarkan tanggal transaksi keluar masuknya barang persediaan, nama distributor, barang masuk (in), barang keluar (out) dan sisa barang yang ada nama konsumen dan tanda tangan (paraf). Kartu stok (persediaan) ini memudahkan pegawai bagian gudang untuk melihat apakah barang atau peralatan yang diminta masih tersedia digudang, selain itu akan memudahkan pegawai apabila ada stok opname sewaktu waktu tinggal mencocokkan kartu stock barang dengan fisik persediaan yang ada digudang.

c. Laporan Pemesanan Kembali (Reorder Report)

Laporan ini mengidentifikasi jenis persediaan yang memerlukan penambahan. Pada PT Mega Prabu Mandiri Cabang Lubuklinggau akan melakukan pemesanan apabila sudah dilakukan rekap pemesanan alat kesehatan yang stok (persediaan) digudang sudah tidak ditemukan kembali atau persediaan barang digudang tinggal sedikit. Biasanya perusahaan akan melakukan purchase order(PO) ke kantor pusat dengan mengisi formulir Purchase Order (PO) sehingga memudahkan dalam pemenuhan pemesanan persediaan dan pengiriman pemesanan kembali. PO ke kantor pusat biasanya membutuhkan waktu kurang lebih satu minggu. Rekap pemesanan ini akan membantu manajer atau bisa sebagai alat pemberitahuan manajer apabila jenis barang yang tersebut dalam rekap pemesanan tersebut memerlukan penambahan atau pembelian, dan ini juga menggambarkan informasi kondisi persediaan yang ada di perusahaan.

d. Laporan Hasil Perhitungan Fisik (Physical Inventory Report)

Laporan ini berisi perhitungan fisik persediaan yang dilakukan secara perpectual. Pada PT. Mega Prabu Mandiri Cabang Lubuklinggau dalam melakukan perhitungan fisik hasil laporannya adalah laporan stok (persediaan) gudang. Dengan laporan ini, maka perhitungan persediaan barang yang ada digudang dapat dilakukan. Dan dalam laporan ini berisikan stok (persediaan) barang yang ada digudang, harga dan total harganya. Laporan ini bermanfaat sebagai pembanding untuk menjamin akurasi catatan persediaan. Laporan 
hasil perhitungan fisik menggambarkan saldo persediaan akhir yang ada digudang atau menggambarkan keluar masuknya persediaan barang sehingga sewaktu waktu kita mau mengetahui sisa persediaan bisa dengan cepat ditemukan. Laporan ini berisikan no urut transkasi, naman gudang, tanggal transkasi atau pencatatan, keterangan berisikan nama distributor dan konsumen, jenis barang, kode barang karena kode masing-msing barang berbeda-beda, nama barang, jumlah barang masuk, jumlah barang keluar, dan saldo barang yang ada digudang. Laporan hasil perhitungan fisik ini juga sangat membantu karyawan dalam melakukan pengendalian persediaan sehingga jangan sampai terjadi kekosongan persediaan dalam gudang sehingga transaksi pembelian dan penjualan dapat berjalan dengan lancar.

PT. Mega Prabu Mandiri Cabang Lubuklinggau sudah membuat semua Iaporan yang dibutuhkan yaitu laporan status persediaan, laporan laporan perjenis persediaan, laporan pemesanan kembali, dan laporan hasil perhitungan fisik persediaan sehingga bisa dikatakan system persediaan.

\section{Catatan Akuntansi}

Catatan akuntansi yang digunakan pada PT. Mega Prabu Mandiri Cabang Lubuklinggau antara lain pencatatan pembelian, pencatatan penjualan, pencatatan stok (persediaan) barang dan pencatatan kas kecil.Semua pencatatan yang berkaitan dengan sistem persediaan sudah dilakukan dengan komputerisasi. Setiap terjadi transaksi baik transasi pembelian, transaksi penjualan, dan transaksi kas kecil langsung diinput ke komputer sehinggan ini akan memudahkan karyawan dalam menemukan data yang diperlukan. Untuk catatan stok (persediaan) barang juga dilalukan setiap ada barang masuk atau keluar langsung dicatatat kedalam computer sehingga pada akhir bulan tinggal melakukan stock opname untuk mencocokkan persediaan yang ada digudang dengan catatan yang ada di komputer.

Pencatatan penjualan untuk mencatatat transaksi penjualan alat alat kesehatan pada pelanggan maupun pada konsumen mandiri disekitar wilayah Lubuklinggau, Musi Rawas, dan Musi Rawas Utara. Fungsi pencatatan penjualan adalah untuk melihat penjualan barang per item setiap tanggal atau sesuai periode yang di cari. Pencatatan penjualan ini tujuannya untuk mengetahui berapa banyak jumlah penjualan setiap bulannya selain itu bisa digunakan sebagai alat pengendalian atas pengeluaran barang persediaan. Berapa banyak barang yang keluar juga bisa diketaui dari penjualan barang dagang. Pencatatan persediaan barang untuk mencatat mutasi barang persediaan dan tujuannya untuk mengetahui persediaan barang yang masih ada digudang dan untuk memudahkan dalam pengawasan serta kroscek ulang apabila sewaktu waktu ada yang membutuhkan barang sehingga memudahkan karyawan untuk menemukan barang yang ada digudang. Pencatatan kas kecil digunakan untuk mencatata pengeluaran-pengeluaran yang tidak bisa menggunakan cek atau pengeluarannya terlalu kecil nominalnya sehingga dibentu kas kecil sehingga memudahkan operasional perusahaan, biasanya kas kecil ini digunakan untuk belanja alat tulis kantor, ongkos kirim barang, bayar WIFI, bayar konsumsi, dan lain-lain.

Pencatatan persediaan pada PT. Mega Prabu Mandiri Cabang Lubuklinggau sudah menggunakan system perpetual dimana setiap terjadi penerimaan maupun pengeluaran barang langsung dicatat dalam kartu stock barang sehingga sewaktu waktu ingin mengetahui sisa barang yang ada digudang bisa diketahui. Dan ini akan 
memudahkan bagian gudang dalam melakukan pengawasan dan pengendalian persediaan barang dagang dan memudahkan bagian pembelian untuk melakukan rekap pembelian barang dagang.

\section{Prosedur Pemrosesan Transaksi Persediaan}

Prosedur pemrosesan transaksi persediaan merupakan prosedur pencatatan yang berkaitan dengan perolehan persediaan pada PT. Mega Prabu Mandiri Cabang Lubuklinggau. Transaksi ini dimulai dari adanya proses pemesanan barang atau peralatan kesehatan apabila barang sudah tersedia digudang, pemesanan barang ke distributor, penerimaan barang yang dipesan dan proses penjualan kepada konsumen kembali. penjualan kepada konsumen, pengecekan barang digudang, pengiriman barang yang dipesan kepada konsumen apabila barang sudah tersedia digudang.

Proses pemesanan dilakukan apabila sudah ada rekap barang yang akan dipesan berdasarkan pemesanan dari konsumen. Pemesanan dilakukan karena sudah tidak tersedia lagi barang-barang yang ada digudang. PT. Mega Prabu Mandiri Cabang Lubuklinggau dalam melakukan pemesanan harus melalui kantor pusat, PO yang dibuat harus mendapat validasi dari pimpinan kantor pusat di Prabumulih dan proses pemesanan melalui PO harus menunggu kurang lebih satu Minggu. Apabila pemesanan barang dagang sudah mendapat validasi baru dilakukan pemesanan kepada distributor dan perusahaan di Linggau tinggal menunggu pengiriman barang dari distributor.

\section{Pengendalian Aplikasi}

Pada PT. Mega Prabu Mandiri Cabang Lubuklinggau sudah melakukan pengendalian Aplikasi terhadap sistem persediaan yang ada. Selama ini dalam operasional PT. Mega Prabu Mandiri Cabang Lubuklinggau menggunakan aplikasi yang sudah ada di komputer melakukan pengendalaian terhadap input maupun output terkait dengan sistem persediaan.Pengendalian persediaan dilakukan sudah berdasarkan pada pengawasan barang masuk dan keluar, serta pencatatan masih manual tapi sudah terkomputerisasi. Pengendalian sistem aplikasi dilakukan untuk transaksi barang masuk, transaksi barang keluar dan PPN, Laporan stok, pembelian barang persediaan, penjualan barang persediaan, dan rekap faktur semua dilakukan oleh bagian IT perusahaan.

Pengendalian sistem ini bertujuan untuk pengawasan terhadap transaksi yang berkaitan dengan persediaan, umpamanya transaksi barang masuk fungsinya untuk mencatat transaksi barang masuk yang harus diperhatikan adalah No. faktur distributor, tanggal faktur distributor, tanggal jatuh tempo faktur, masukan nama barang, no. lot, expire date, kalau ada diskon dan PPN jangan lupa di masukan.Untuk mencatat transaksi barang keluar PPN yang harus diperhatikan adalah tanggal faktur keluar, tanggal jatuh tempo faktur, masukan nama barang, no. lot, expire date, ceklis kolom PPN. Pencatatan lapora stok fungsinya untuk mencatata Laporan Stok persediaan yang harus diperhatikan adalah untuk melihat histori barang masuk dan keluar per tanggal dan fungsi tombol exsport Untuk menyalin data ke Excel. Berdasarkan pembahasan pengendalian aplikasi yang berkaitan dengan sistem persediaan pada PT Mega Prabu Mandiri sudah cukup baik.

\section{E. Kesimpulan dan Saran}

1. Kesimpulan 
Berdasarkan hasil dan pembahasan dapat disimpulkan :

a. Pembelian Barang pada PT. Mega Prabu Mandiri Cabang Lubuklinggau dilakukan dengan dua cara, pertama pembelian secara langsung dimana pembelian barang-barang bahan habis pakai ( BHP) dan barangnya sudah tersedia di gudang. Kedua pembelian dengan menggunakan PO (Purchase Order) dimana pembelian ini dilakukan karena barang yang dipesan merupakan barang-barang yang berukuran besar.

b. Penjualan peralatan kesehatan pada PT. Mega Prabu Mandiri Cabang Lubuklinggau ada yang secara tunai dan ada penjualan yang pembayarannya jatuh tempo. Penjualan tunai dilakukan pada konsumen mandiri dan penjualan yang berdasarkan jatuh tempo untuk konsumen tetap perusahaan.

c. laporan yang dihasilkan berkaitan dengan sistem persediaan pada PT. Mega Prabu Mandiri Cabang Lubuklinggau sudah membuat laporan yang terdiri dari laporan status persediaan, laporan laporan perjenis persediaan, laporan pemesanan kembali, dan laporan hasil perhitungan fisik persediaan.

d. Catatan akuntansi yang digunakan pada PT. Mega Prabu Mandiri Cabang Lubuklinggau antara lain pencatatan pembelian, pencatatan penjualan, pencatatan stok (persediaan) barang dan pencatatan kas kecil.

e. Pada PT. Mega Prabu Mandiri Cabang Lubuklinggau dalam melakukan prosedur pemrosesan transaksi persediaan sudah melalui beberapa tahapan. PT. Mega Prabu Mandiri Cabang Lubuklinggau dalam melakukan pemesanan harus melalui kantor pusat, PO yang dibuat harus menunggu validasi dari pimpinan kantor pusat.

\section{Saran}

Berdasarkan kesimpulan diatas, perusahaan diharapkan dapat meningkatkan pengendalian sistem persediaan antara lain:

a. Dalam mengelola sistem persediaan, perusahaan lebih menekankan pada uji kelengkapan data dan validitas transaksi

b. Petugas melakukan verifikasi dari laporan kontrol untuk memastikan bahwa seluruh transaksi telah diproses

\section{DAFTAR PUSTAKA}

Andi, 2015. Sistem Informasi Akuntansi. Yogyakarta : TMBooks.

Anastasia Diana dan Lilis Setiawati. 2019. Sistem Informasi Akuntansi. Yogyakarta: Andy

Azhar Susanto. 2010. Sistem Informasi Akuntansi. Jakarta: Salemba Empat.

Danang Sunyanto. 2016. MethodologiPenelitianAkuntansi. Bandung: Rafika

Harnanto. 2012. Akuntansi Keuangan Menengah Buku 1 Cetakan Ketiga.

Yogyakarta: BPFE Yogyakarta 
Krismiaji. 2010. Sistem Informasi Akuntansi.Yogyakarta. Sekolah Tinggi IlmuManajemen YKPN.

Lilis Puspitawati dan Sri Dwi Anggraini, 2011. Sistem Informasi Akuntansi. Yogyakarta : Graha IImu.

Mulyadi. 2016. Sistem Akuntansi. Jakarta : Salemba Empat. 